\title{
HOW DID WE END UP HERE? \\ THEOLOGICAL EDUCATION AS MINISTERIAL FORMATION IN THE BRITISH BAPTIST COLLEGES
}

\author{
ANTHONY CLARKE \\ Regent's Park College, Oxford University, UK
}

\section{ABSTRACT}

This paper explores developments in the Baptist colleges in England and Wales principally over the last 40 years, suggesting that paradigms which have focussed on education and training have developed and are developing into a paradigm which stresses formation. It offers eight key areas, including formation, where there have been important changes which together inform the shared contemporary practice of these colleges. Alongside engaging with the published literature on this subject, the paper also draws on the private papers of key participants in these developments and some personal interviews. The paper concludes with a summary of these eight areas in the form of commitments by these Baptist colleges.

KEYWORDS ministerial formation, theological education, university, practical theology, British Baptist colleges.

\begin{abstract}
Ministers are not simply 'trained' in skills required, or 'educated' in the academic discipline of theology and its many sub-disciplines. While both are certainly major components of ministerial courses, there is a third area, one concerned with character and spirituality, ethics and human relationships, that is essential to ministry. When these aspects are added to the development of skills and the acquisition of knowledge and understanding, there is a complex mix that is generally referred to as 'formation.' ${ }^{1}$
\end{abstract}

So states a recent document presented to the Baptist Union Council on the nature of Baptist ministry, ${ }^{2}$ although it is not entirely clear as to who generally refers to this as formation. This Baptist Union document uses 'formation' to describe the overall mix of three areas, whereas it is also used extensively to describe the third area of character and spirituality, and so formation sits alongside education and training as three aspects of one process of preparation. But what is clear is that we are now in a different place, utilising different language to previous generations.

Yet how did we end up here? The aim of this paper is to chart some of the significant influences, particularly over the last fifty years, in shaping what is now normally described as ministerial formation in the Baptist Colleges which are members of BUGB ${ }^{3}$. In the words of the Baptist Union document the history of this development may be described as a complex mix, or perhaps better as a number of tangled roots from which current practice has emerged. It ought to be recognised at the beginning that there is an inevitable gender bias to the story, and much of the recent history of

\footnotetext{
1 Patterns of Ministry among Baptists: A Review of The Register of Covenanted Persons Accredited for Ministry A Report of the 'Review of the Register Working Group', presented to BUGB Council in November 2011, p. 11.

2 The specific impetus to the paper was the recommendation to establish a register of nationally accredited church workers (a permanent diaconal order) alongside the register of nationally accredited minsters. But the paper took the opportunity to reflect on the developing Baptist theology of ministry.

${ }^{3}$ This paper concentrates on the four Colleges in England (Northern Baptist Learning Community, Bristol Baptist College, Spurgeon's College and Regent's Park College) and the South Wales Baptist College. The Scottish Baptist College and Y Coleg Gwyn are also affiliated with BUGB, but are more deeply immersed in the life of other Unions and are not considered here.
} 
ministerial formation has been shaped by men. But within this history we will suggest eight important factors that feed into contemporary practice.

\section{The centrality of a university education}

John Nicholson, a retired Baptist Area Superintendent, reflects on the significant differences between his experience at Regent's Park College in the 1950s and his perceptions of contemporary ministerial formation. He describes a pattern that focussed heavily on academic study in College for the Oxford BA, with the presumption that being sent out into churches would give sufficient practical experience. ${ }^{4}$ This is the world of education as training the mind. ${ }^{5}$ Indeed, one unnamed Baptist College Principal from the 1960s is reported to have said 'train a man's mind and the rest will take care of itself. ${ }^{6}$

Such an emphasis had been one long standing tradition among Baptists, which Paul Ballard traces back to the seventeenth century and the puritanical demand for an educated clergy. ${ }^{7}$ The founding of Bristol Baptist College in 1679 by Edward Terrill's gift deed witnesses to this desire to provide for the education of young men for ministry by someone 'well skilled in the tongues of Hebrew and Greek. ${ }^{8}$

This, though, is not the only strand of tradition, as intertwined was the opposite opinion, for 'to be destitute of learning has been esteemed a good proof of a preacher's mission from above ${ }^{9}$. Such responses were more dominant in the first two centuries of Baptist life but still continued thereafter. Although Spurgeon's College taught a wide curriculum including maths, science and ancient languages, alongside theology, Spurgeon tended to reject academic qualifications as largely irrelevant ${ }^{10}$, perhaps shaped by his own education ending at secondary school, and was concerned that too great a store was placed on theological learning. ${ }^{11}$ Later at the dawn of the twentieth Century there were fierce debates in response to the Baptist Union's desire to introduce the concept of ministerial accreditation to safeguard the use of a proposed Sustentation Fund, with the first Ministerial Recognition Committee established in 1896, and the later introduction, or imposition of the Baptist Union examination. ${ }^{12}$ Behind this was both some sense of competition and antagonism between those who had trained at the Baptist Colleges and those who had entered ministry through other routes, together with a mixed view of university education. Randall suggests that at the turn of the twentieth century only eight per cent of Baptist ministers had been connected with a University ${ }^{13}$ (this is not the same as being trained in a Baptist College) and there were clear differences of opinion often categorised as those at the heart of the Union's structures being supporters of high levels of education with others concerned that 'ministers empty churches by degrees'! $!^{14}$ The debate about an educated ministry continued Into the second half of the twentieth century and R E Cooper, in telling the history of Regent's Park College, reflects that there was still a desire among some for uneducated ministry as well as those churches which prize degrees above

\footnotetext{
4 John Nicholson 'Changing Attitudes', The Fraternal 269 (Jan, 2000), p. 11.

${ }^{5}$ Michael Taylor comments, in 1982, that it was not that long ago in the 1950s that remarkably little practical training was given, just degrees in theology. In $2^{\text {nd }}$ lecture on 'The Theology of Spiritual Formation' at $14^{\text {th }}$ Atlantic Seminar in Theological Education, 1982, p. 3 (in his personal papers in the Angus Library, Regent's Park College).

${ }^{6}$ Quoted by Michael Taylor, 'The Free Churches Selection and Training' in Christian World, (Jan 1979).

7 Paul Ballard, 'The Emergence of Pastoral Studies' in Paul Ballard, ed., Foundations of Pastoral Studies and Practical Theology, (Cardiff: University College, 1986), p. 9.

8 Norman Moon, Education for Ministry, (Bristol: Bristol Baptist College, 1979), p. 1.

${ }_{9}^{9}$ Mike Nicholls, Lights to the World: A History of Spurgeon's College 1856-1992 (Harpenden: Nuprint, 1994), p. 24, quoting St Andrew's Street Church Book, Cambridge, 72A).

${ }^{10}$ Peter Shepherd, The Making of a northern Baptist College, (Manchester: Northern Baptist College, 2004), p. 25.

11 Nicholls, Lights to the World, pp. 30-1.

12 See lan Randall, Baptists of the Twentieth Century, (Didcot: Baptist Historical Society, 2005), pp. 64-8 and Douglas Sparkes, An Accredited Ministry (Didcot: Baptist Historical Society, 1996).

${ }^{13}$ Randall, Baptist of the Twentieth Century, p. 64.

${ }_{14}$ Ibid, quoting lan Sellers (ed.), Our Heritage: The Baptists of Yorkshire, Lancashire and Cheshire 1647-1987 (Leeds: Yorkshire Baptist Association, 1987), p. 128.
} 
vocation ${ }^{15}$, and David Russell, then General Secretary of BUGB, suggested that 'within the Christian Church there is still a fair measure of obscurantism which encourages the closed mind and a fair measure of prejudice and dogmatism. ${ }^{16}$

But the trajectory of the Colleges has been firmly towards greater University connections. The end of the nineteenth century saw the Baptist Colleges develop stronger relationships with the burgeoning Universities and so offer degrees to their students. Regent's Park was one of the Divinity Schools of London University from 1900; Bristol Baptist College became an associated College of Bristol University when it was founded in 1909; the Baptist Colleges in the north of England were involved in Victoria Federal University from its beginning in the 1880s and the Manchester College, one of the two Colleges later to become Northern Baptist College, was at the heart of the developing of the theology faculty at the new University of Manchester in $1903 .{ }^{17}$ The Charter for the University of Wales was signed in 1893 and the postgraduate degree became available for students at Cardiff in 1896, who previously had sent students on to Regent's and later Bangor to complete the London BD. In 1936 the Cardiff School of Theology was formed further strengthening the relationship between the Baptist College and the University. ${ }^{18}$

Spurgeon's College, so re-named in 1923, also began considering the possible affiliation with London University in 1902, which was finalised in the 1930s, while also formally aligning itself with the Baptist Union in 1938. Regent's Park moved from its eponymous home to Oxford in 1927, deliberately to strengthen the Free Church presence in one of the ancient Universities. Further, the out-workings of the 1870 education act together with the Colleges formally joining the Baptist Union in 1873 seemed to have combined to have a positive effect on the academic standards of those applying, thus enabling greater learning and gradually raising standards. ${ }^{19}$

The effect of a growing relationship with the Universities was not simply to provide an external validation for an approved standard of theological education, so that a diploma level qualification in theology became the expectation for accredited pastoral ministry ${ }^{20}$, but it also brought clearly and institutionally together preparation for ministry with the teaching of theology in an academic and increasingly secular setting. This was not a straightforward process.

Theological developments, especially in the areas of biblical criticism, increasingly became areas of Union controversy, as some had always feared ${ }^{21}$. When T R Glover wrote in the Times in March 1932, reflecting on the previous 50 years of the Free Churches, he cited the involvement of Baptists in higher and theological education as a cause to celebrate, provocatively suggesting this was represented and secured by the Union's stand against Spurgeon in the Downgrade Controversy. Nicholls, in his history of Spurgeon's College suggests that in the early years of the twentieth century Spurgeon's was far behind the other London Colleges academically, which it would seem Nicholls regrets, as the other Colleges were influenced by London University's methods in teaching and examination. ${ }^{22}$ This would certainly not be the case today.

This validation also entailed a commitment, however explicitly and positively this was embraced, to the prevailing understanding of secular University education. David Kelsey, in discussing the theological education debate of the 1980s, writes of the 'Berlin' approach to education, rooted in the establishment in Berlin in 1810 of a research University, shaped by Enlightenment principles and

${ }^{15}$ R. E. Cooper, From Stepney to St Giles': The Story of Regent's Park College 1810-1960 (London: Carey Kingsgate, 1960,) p. 126.

${ }^{16}$ D. S. Russell, in 'The College and its Future', an address given on the retirement of L. G. Champion and the inauguration of W. M. S. West as President of Bristol Baptist College, 1971 (in his personal papers in the Angus Library).

17 Shepherd, Making of a northern College, pp. $110 \mathrm{ff}$ and 146.

18 D. Hugh Matthews, From Abergavenny to Cardiff: History of South Wales Baptist College (1806-2006) (Abertawe: Gwasg Ilston, 2007), pp. 23-6.

${ }^{19}$ Although there were still concerns at the turn of the century about the need for preparatory education for those entering the Colleges. See Sparkes, An Accredited Ministry, p. 14 and Shepherd, Making of a northern College, p. 99.

${ }^{20}$ See Chris Ellis and Malcolm Goodspeed, 'Towards a New List: Proposals for the Restructuring of the List of Accredited Ministers of the Baptist Union of Great Britain (Draft 5), Doctrine and Worship Committee (July 1998).

${ }^{21}$ See Randall, Baptists of the Twentieth Century, pp. 133-6.

22 Nicholls, Lights to the World, p. 114. 
committed to a Wissenschaft approach, that is disciplined, critical and open enquiry which not only taught the results of critical enquiry but also engaged in such critical research as the pursuit of knowledge. ${ }^{23}$

Without doubt connections between the Baptist Colleges and Universities did much to boost the status of the Colleges and those who graduated from them, and as attendance at University increased in the 1950s and 1960s so Baptist Ministers were able to stand alongside others as graduates. What then became established among Baptists in the early years of the twentieth century, experienced by John Nicholson and taken for granted today, was the acceptance of an educated ministry, and not just in terms of the status of the minister, but, through intentional engagement with the wider academy, with all that it might offer and all the challenges it brought. ${ }^{24}$ David Russell, describing the role of the Colleges to produce mature men and women of God, suggests,

among other things this will mean the creation of an educated and cultured ministry. This has been characteristic of our Baptist theological education in the past and I hope it will continue to be... And this in turn will mean the encouragement in our students of an open-minded search for the truth wherever it be found. ${ }^{25}$

Our Baptist Colleges have different University relationships, which have changed and are still changing, from being a geographically distant validated College, such as Spurgeon's to being fully rooted and immersed in the centre of a University, like Regent's Park. The Colleges have also developed in different ways, diversifying and adapting in the light of practical and financial constraints which have meant that Baptist ministerial students alone have not been a sufficient student body. But all are firmly rooted in Higher Education settings, able to draw on the resources they offer, committed to open critical enquiry, and subject to the inspections and reviews concomitant with such affiliations. ${ }^{26}$ Alongside the positive benefits, there has been some recognition of the constraints of University affiliation over the years, especially the constraints laid on the curriculum by a degree programme. ${ }^{27}$ And the strand of Baptist thinking suspicious of academia has continued. Stephen Pattison writes in the 1980s of a conservative turn in British church life with less interest in the liberal ethos of secular Universities, and the financial attraction of cheaper church-centred courses. ${ }^{28}$ With the very recent changes in Higher Education funding, which have had significant impact in Colleges involved in Theological Education, for example in the response by the Church of England in Common Awards, questions may be raised again in some quarters about the value of validating with a Higher Education partner. But at present University validation is both a symbol of and commitment to open critical enquiry and is at the heart of how the Colleges approach theology.

\section{The rise of pastoral studies}

Yet there was a growing disquiet in the 1960s about the suitability, especially the practical relevance of the education and training being offered in the Baptist Colleges. In 1960 Cooper suggests that at Regent's there is not enough opportunity for experience, not enough teaching on spirituality and some concerns about the range of the Oxford BA, with a deep yet narrow focus on Scripture. ${ }^{29}$ David

\footnotetext{
${ }^{23}$ David Kelsey, Between Athens and Berlin: The Theological Education Debate (Grand Rapids, MI: Eerdmans, 1993), pp.

24 The development of the Council for National Academic Awards in 1965 gave the opportunity for independent Colleges, as well as polytechnics, to teach for and award degrees through a national, secular, higher education body.

${ }^{25}$ Russell, 'The College and its Future'.

26 These include Quality Assurance through the QAA subject benchmark for theology and religious studies.

27 See, for example, as early as 1967 David Russell makes this point in a paper 'Theological Education in the Free Church Tradition: The British Situation', in private papers in the Angus Library.

28 Stephen Pattison, 'Research, Resources and Threats' in Ballard, ed., Foundations of Pastoral Studies, pp. 144-5.

${ }^{29}$ Cooper, From Stepney to St Giles', pp. 128-31.
} 12-19. 
Russell, in the year that Northern Baptist College was formed and he became joint Principal, began an address to the Baptist World Alliance with the growing discontent among younger ministers that the Colleges were seeking to produce professors and not ministers ${ }^{30}$. A few years later in 1973, a former Regent's student, Gethin Abraham-Williams wrote a series of three articles for the Baptist Times pleading that Colleges give men [sic] practical training as well as academic learning, listing over 40 practical topics he felt were not covered. ${ }^{31}$

But significant change was on the way. Pastoral studies was launched as an academic subject at Birmingham University in the 1960s through the work of Professor Gordon Davies and then Bob Lambourne. ${ }^{32}$ Similar appointments at Cardiff and Manchester followed. The Universities Conference on Pastoral Studies, later to become British and Irish Association of Practical Theologians (BIAPT), was inaugurated in 1970 to encourage discussion and development in the subject. Paul Ballard, a Baptist Minister appointed to teach at Cardiff in 1968, looking back over the unfolding process suggests that Pastoral Studies 'is not really an innovation. It represents a further stage in the continuing tradition of practical theology. ${ }^{\prime 3}$ Whereas it would certainly be wrong to overstress the newness of this development, this does seem an important milestone in the journey which has had a long lasting impact.

It is interesting that these changes begin not in the theological Colleges training minsters, but in University departments. For decades, even centuries, theology, as a discipline, had needed, somewhat ironically given the origins of Universities, to justify its place within the University on academic grounds. This happened in various ways in the 1960s, including the development of Pastoral Studies as professional education and the significant inter-disciplinary work which the spirit of optimism and co-operation of the age encouraged. Ballard suggests a number of important contributing factors such as the general growth of professional training in areas like administration and social welfare, the professionalization of the clergy, especially in the Church of England, and the influence of practice from other parts of the world, notably liberation theology from the developing world, and the movements of Clinical Pastoral Education and Pastoral Counselling from the United States. ${ }^{34}$

David Russell's address back in 1964 seems to have recognised the issues involved, that the more practical side of the courses were 'full of bits and pieces', and also offers clear insight into the necessary way forward. ${ }^{35}$ He rejects the false dichotomy between theoretical and practical knowledge, between becoming professors and mere technicians who are good at the mechanics of churchmanship, arguing for an integrated approach. This is one which does not simply 'apply' theology to different contexts, which recognises the significance of the whole experience and environment and not just the course of study, and which would produce spiritual leaders, not full of information but able to live in the world as true interpreters of the Gospel, enabling the ministry of the Church in the world. He recognises that British Colleges may have much to learn from his American audience especially about the centrality of 'field-work' and the necessity of learning through pastoral experience. Despite Russell's foresight it will be some time before these changes are realised more generally in the British context.

What seems clear from the origins of Pastoral Studies in University departments of theology is that, despite the influence of professional training, Pastoral Studies was not seen simply as ministerial training, although it was clearly closely connected. The desire of the early practitioners was to see Pastoral Studies as a legitimate theological and academic discipline in its own right,

\footnotetext{
30 David Russell, 'Practical Training for the Ministry in Britain', 1964 (in private papers in Angus Library).

${ }^{31}$ Baptist Times 13, 20, 27 September, 1973.

32 Paul Ballard, ed., Foundations of Pastoral Studies and Practical Theology (Cardiff: University College, 1986), pp. 5-8.

33 Ballard, ed., Foundations of Pastoral Studies, p. 5.

34 Paul Ballard, 'The Emergence of Pastoral Studies' in Ballard ed., Foundations of Pastoral Studies, pp. 9-18. See also Taylor, $2^{\text {nd }}$ lecture on 'The Theology of Spiritual Formation', p. 3.

35 Russell, 'Practical Training for the Ministry'.
} 
engaging with social sciences as an equal partner. ${ }^{36}$ Pastoral Studies arose from and contributed to the prevailing concern in the 1960s for human flourishing with the desire that it be studied by a wider group than church ordinands, although this aspect remained central.

No longer is it possible to assume that it is enough to provide as a basis for ministerial practice what was once called 'hints and tips' from experienced practitioners... for better or worse, preparation for and the sustaining of ministry is seen to need conscious formation and reflection. ${ }^{37}$

The most significant and long lasting contribution of Pastoral Studies was in the realm of methodology. The parallel and intersecting rise of sociology and psychology, the advances in learning theory and adult education, and the influence of practical field education from both professional training and the Clinical Pastoral Education movement all combined to challenge the Schleiermachian dominance of the deductive model. The four-fold division of theology into Biblical, Historical, Systematic and Practical which had emerged from the German model of Wissenschaft and had significantly influenced Western theological practice, reserved a real place for practical theology, but as the pinnacle of a deductive process derived from first principles. That which was discerned as true from the Bible, history and then systematics was then applied into practice. The challenge to this theological method was the development of critical reflective practice, which took the experience of ministry in placements and through field education, in secular as well as church settings, as an important contribution to the theological discussion within a multi-disciplinary approach - what is now commonly referred to as theological reflection. Nicholson reflects that while in the 1950s he came to Oxford to 'read theology', ministerial formation is now about 'doing theology'. ${ }^{38}$ In a later empirical survey of the development of Masters courses in practical theology, the language now preferred to Pastoral Studies ${ }^{39}$, Ballard summarises that 'practical theology is an academic field primarily defined by method and only secondarily by a sense of content. ${ }^{\prime 40}$

This development of Pastoral Studies as a theological discipline is one moment in an on-going debate on the relationship between theory and practice which extends as far back as Aristotle and his distinction between 'theoria' and 'praxis' as alternative and separate approaches. As such it seeks an integrative approach, rejecting both the priority of theory which characterised much of the modern theological tradition and the Marxist priority of praxis, which had influenced the development through liberation theology. This is not to say such practice and methodology was immediately adopted, either in Baptist Colleges or beyond. The reality was much slower and more complex, but the development of Pastoral Studies in the 1960s was a real turning point in methodology, so that the ability to 'think theologically in the sense of being able to relate theology to contemporary realities and problems and to function theologically through the whole range of pastoral situations ${ }^{\prime 11}$ is now at the heart of this process of formation.

Northern Baptist College, under Michael Taylor had led the way, and the other Colleges were catching up. Arriving as Principal in 1969, aware of the growing dissatisfaction with theological

\footnotetext{
${ }^{36}$ See the various articles in Ballard, ed., Foundations of Pastoral Studies, perhaps especially, John Wesson, 'How Cinderella might get to the Ball: Pastoral Studies and its Relation to Theology', pp. 53-64.

${ }^{37}$ Ballard, ed., Foundations of Pastoral Studies, p. 26.

38 Nicholson, 'Changing Attitudes', p. 11.

${ }^{39}$ Ballard recognises the developments by the mid-1980s. Pastoral Studies might be thought to embrace the sociopolitical too completely and lose the theological aspect; pastoral theology might appear to be limited to ether the work of the pastor or of pastoral counselling. While wishing to see some place for these, Ballard recognises the comprehensiveness of 'practical theology' which subsequently has become more standard. Paul Ballard, 'Moving on From Here' in Ballard, ed., Foundations of Pastoral Studies, p. 146.

40 Paul Ballard, Practical Theology: Proliferation and Performance (Cardiff: Religious and Theological Studies, Cardiff University, 2001), p. 61.

${ }^{41}$ This is Russell's phrase back in 1967, in 'Theological Education in the Free Church Tradition'. Yet in 1975 Taylor notes that the strength of the Colleges was in knowledge of the Christian tradition, but their weakness was in theological reflection, in a paper prepared for Ecumenical Consultation on the role of Theological Colleges (in private papers in Angus Library).
} 
education, Talyor took from the beginning a more radical approach which played down the traditional stresses on biblical languages and systematic theology in favour of a course which strongly related theory to practice, and offered a constant dialogue between the church and contemporary culture with an openness to other disciplines. ${ }^{42}$ Under his leadership the College developed their whole degree course around contextual theology. Here were the fruits of the rise of Pastoral Studies. In 1975, reflecting on current trends in the Baptist Colleges, Taylor notes how the Colleges had responded in different ways to the concerns of the ministers and the rise of Pastoral Studies. Cardiff and Manchester had developed University diplomas in Pastoral Studies, Regent's had developed its own in house course and Spurgeon's was re-working its degree programme to include this. ${ }^{43} \mathrm{~A}$ few years later Taylor would write to his fellow Baptist ministers, that 'forming a person to be such a reflective theologian rather than teaching a person a lot about theology is what theological education is ultimately about. ${ }^{44}$

As an illustration of the case ${ }^{45}$, minutes from the Regent's Council and Executive of the College show an increase in the number of outside speakers brought into tackle more 'practical issues' alongside the four full time academic staff, leading to the announcement in early 1978 that a threeyear Pastoral Training Course had been mapped out. ${ }^{46}$ This comprised a weekly session on Monday afternoons together with sessions on homiletics, elocution and sermon class.

This then led to the appointment in June 1978 of Revd Arthur Jestice as part-time, nonstipendiary, Tutor in Pastoral Practice. Jestice was a former student and long term supporter of the College who had recently retired as Minister of St Andrew's Street Baptist Church, Cambridge and moved back to the Oxford area. After some sustained discussions about the introduction of a fourth pastoral year after the completion of the BA, along the model already followed by Spurgeon's and Cardiff, ${ }^{47}$ the integration of greater elements of Pastoral Studies throughout the three years was the chosen way forward. ${ }^{48}$ Paul Ballard's research in the mid-1980s ${ }^{49}$ revealed four approaches to Pastoral Studies: as one module in the course, academically equal to others; as a separate course run concurrently with the academic programme; as a fourth year, either in College or as an intern; as more fully integrated and the whole theological project rethought. Certainly at Regent's at the time it was clearly the second pattern, of a distinct and concurrent course, which was adopted.

The real change occurred, however, with the appointment of Revd Bruce Keeble as the first full time, stipendiary tutor in Pastoral Theology, to begin work in January 1981. The desire was expressed to find a fifth tutor with a 'specialist teaching interest in pastoralia' who would be able to 'work at the integration of the academic course with pastoral needs's0 and do so full time. But perhaps more significantly would be the alternative methodology, drawn from the developing academic aspect of Pastoral Studies, that Keeble would gradually bring into the ministerial formation. This is not to say that before this time there was a lack of interest in the practical issues of ministry, or of developments happening within the wider constituency, and there is some evidence of a gradual progression. The paper produced for the College Executive on 'Ministerial

\footnotetext{
${ }^{42}$ Shepherd, The Making of a northern College, pp. 229-30.

${ }^{43}$ In a paper prepared for Ecumenical Consultation on the role of Theological Colleges, in private papers in Angus Library.

44 Taylor, 'Ministerial Training at Northern College', The Fraternal 196 (July, 1981), p. 6.

${ }^{45}$ Similar changes may be detected in other Colleges. Cardiff, for example, had already developed a Diploma in Pastoral Studies in 1964 and then an MTh in early 80s and Neville Clark was appointed as Tutor in NT and Pastoral Theology in 1975. Matthews, From Abergavenny to Cardiff, pp. 33-5.

${ }^{46}$ RPC Council Minutes, 7 January 1978.

47 This is the main content of a paper 'Ministerial Training at Regent's' presented by Barry White, then Principal, to the Executive Committee on 3 February 31979.

${ }^{48} \mathrm{At} \mathrm{Bristol}$, which always sought to have vocational training alongside academic rather than in a $4^{\text {th }}$ post-graduate year Keith Clements was appointed in 1977 to develop pastoral training initially on a part-time basis. See Norman Moon, Education for Ministry, pp. 96-98.

${ }^{49}$ Ballard, 'Survey of the Field', pp. 31-2.

${ }^{50}$ RPC Council Minutes, 23 June 1979. The willingness to develop a specialist skill such as counselling or sociology was included in the person specification drawn up. Executive Minutes, 15 September 1979.
} 
Training at Regent's' concludes that 'it is the utmost importance, in the view of Regent's tutors, that there should be close contact between both the 'academic' and 'practical' sides of training so one does not operate independently of the other' ${ }^{51}$. Yet Keeble himself felt that while this developing methodology could be introduced to those on the newly formed Congregation-based course, the pattern for College-based students continued with relatively few changes ${ }^{52}$ and the overall impression is of a more applied methodology, with a predominance still given to academic study, rather than the theological significance given to practice in the developing field of practical theology. This reveals again the significance of Michael Taylor. Keeble spent some of his first year researching into what else was happening within the field, at St John's Nottingham and the St Alban's training programme, but especially Northern Baptist College, and he significantly shaped the new Regent's In-Pastorate course in the light of this. Keeble was also significantly influenced by Paul Ballard and the debate around theological reflection. Keeble writes ${ }^{53}$ of his three basic principles: the formation of the whole person, doing theology as a way of life, and beginning with the experiences and letting them ask questions, especially what the experience says about God.

As an academic component in its own right Pastoral Studies remained fragile ${ }^{54}$, with a decreasing desire to enter into multi-disciplinary work, and the emerging practical theology has still struggled at times to find its place within the academy. But a fundamental shift in methodology emerged which has deeply shaped the practice of the British Baptist Colleges. The Report on the partnership between the Colleges and the Union in 1998 affirmed the emphasis on 'doing theology and the whole methodology of theological reflection. ${ }^{55}$ An integrated approach to theory and practice, theological reflection, and the development of reflective practitioners were now at the heart of their work.

\section{The rethinking of theology}

The development of alternative ways of tackling theology through the rise of Pastoral Studies led, in some quarters at least, to the rethinking of theology as a whole, particular in what is termed in America as the 'theological education debate'. A key contribution to this was the publication in 1983 of Edward Farley's influential book Theologia: The Fragmentation and Unity of Theological Education, although this represents a more detailed expression of ideas he had already been suggesting. ${ }^{56}$ Farley's fundamental thesis was that the so called 'encyclopaedic' approach to theology, which divided the whole subject into an increasing number of practically autonomous sub-divisions, as a response to the marginalisation of theology in the University setting, was an unhelpful and false move in the modern period. The result of this, he suggests, is the loss of a sense of unity inherent in theology, as 'knowledge of God', replaced by the teleological unity, proposed by Schleiermacher, based on the contribution that each discipline brought to ministerial training. Rather than theology being a valid pursuit because of the self-evident value of the knowledge of God, theology's place in the University depends on what it contributes to the preparation of leadership for the church, thus rightly sitting alongside law and medicine. ${ }^{57}$ He argues passionately for a return to what he describes as the 'habitus' approach to theology, which he understands as a

\footnotetext{
51‘Ministerial Training at Regent’s', Executive Committee minutes, 3 February 1979.

${ }^{52}$ Expressed in an interview in 2011.

53 In private correspondence.

54 Ballard describes it, in 1986, as a 'small but not therefore insignificant element' in 'The emergence of Pastoral Studies, p. 16. Stephen Pattison notes that, among the threats, there were no more than a dozen university appointments, some part time, with the pioneering post at Birmingham now abolished, in 'Research, Resources and Threats', p. 144. This is part of the more general rise of professional studies and the desire for these to be validated by Universities less familiar with the methodology of critical reflection and suspicious of a skills-based approach.

55'Partners Together - The Colleges and the rest of the Baptist Union of Great Britain' - The Report of the Union / Colleges Partnership Task Group (August 1998), p. 11.

56 See, for example, Farley, 'The Curricular Pattern and its Rationale as an Issue in the Reform of North American Theological Education' in Ministerial Formation 14 (April, 1981), pp. 8-11.

57 See Farley, 'The Curricula Pattern and its Rationale', pp. 8-9 for a summary of this.
} 
'personal disposition (habitus) to understand the things of God [...] that which is presented to faith for its interpretation' ${ }^{58}$ for which he uses the term 'theologia'. ${ }^{59}$

Michael Williams describes Farley's suggestion of a 'habitus' as meaning:

an attitude or disposition of the heart formed by the transformation of the person by the disciplined meditation and study of the sacred texts together with a disciplined study of human life. Right theology is seen as coming not from a unified theological system but rather from people made whole doing theology. ${ }^{60}$

Farley's work has been influential and has helped shape the development of theology, but has not been without its critics. Williams himself argues that he is being too individualistic and also too naïve. The integration that is being sought is found too exclusively in the individual who brings everything together in her own person, and it is integration which seeks a wholeness that is never attained. If formation is seen as life-long and indeed Christologically and eschatologically orientated the ideal need not be naïve, but Williams' comments insist that 'thelogia' must include the way that theology is taught, so that integration happens deliberately in the curriculum, through carefully chosen methodologies. There would still need to be some place in an understanding of formation, for personal and individual integration in terms of life and faith, but this would be based on a different approach to teaching.

John Hadsell pushes further in a different direction, and argues that while Farley wants to keep the rethought theological education in the theological school it is better to locate it much more firmly in the community of faith and in the world. He offers Northern Baptist College in the 1980s as an example at the time where students have secular placements and not just in the church, so that a habitus can be developed in this setting. ${ }^{61}$

Generally in academic circles the fragmentation and specialisation of sub-disciplines has continued, although one of the major recent developments in theological education in British Universities has been the rebranding of faculties and departments as those of religious studies. This offers an interesting comparison and contrast. It may suggest a similar desire to look for an overarching language and methodology in which to integrate the various disparate elements of academic theology, but one more in keeping with a secular University setting.

The Baptist Colleges have also worked hard at not being, and not being perceived to be, separated 'theological schools' distinct from the churches and the world, as they have all sought to engage more intentionally in offering education for the whole people of God and to support the mission of the church in the world. Curricula have been and continue to be developed, seeking integration of the different aspects of theology and of theology and practice in different ways. Farley looks to revive an older paradigm of the knowledge of God appropriate to the faith community as it approaches theology, and this would resonate deeply with the current practice of the Baptist Colleges.

\section{The development of congregation-based patterns}

Following on from the development of the methodology of Pastoral Studies and alongside the discussion on the nature of theology was the development of what is generally known among British Baptists as 'Congregation-based' or Church-based training, or in other ecumenical circles as 'mixedmode' training. In September 1978 Northern Baptist College began an experiment which they

58 Farley, 'The Curricula Pattern and its Rationale', p. 10.

59 See also Bryan Pettifer, 'Education and the Knowledge of God: Towards a model of Theology as a Practical Discipline in Ballard, ed., Foundations of Pastoral Studies, p. 68-9; and Stephen Toulmin 'Theology in the Context of the University' in Jeff Astley, Leslie Francis and Colin Crowder, eds., Theological Perspectives in Christian Formation (Leominster: Gracewing, 1996), pp. 393-405, for further arguments about the integrated and practical nature of theology.

60 Michael Williams, 'The Dichotomy between Faith and Action: Towards a Model for 'Doing Theology" in Ballard, ed., Foundations of Pastoral Studies, p. 44.

61 John Hadsell, 'Faith's Understanding' in Ministerial Formation 26 (May, 1984), p. 8. 
entitled the Alternative Pattern of Training (APT). In this respect Taylor, its chief architect, was partly influenced by developments happening around him particularly in the Church of England, but also patterns of theological education in the rest of the world. Baptists, as well as other denominations, had discussed for some years alternative approaches to ministry and recognised the need to have alternative patterns alongside full-time stipendiary roles $^{62}$ but this had not yet translated into different patterns of ministerial training.

The North West Regional Training Scheme, centred on Manchester, was pioneering part-time training of men in full time secular employment through evenings, weekends, and residential summer schools. There were other examples in the Church of England of similar experiments, for example in Southwark and St Albans and the Methodist Conference in July 1980 wholeheartedly approved a report on 'Alternative Patterns of Theological Education' which proposed both Congregation-based patterns of training and a mixed pattern of study and secular employment to happen alongside traditional residential courses. ${ }^{63}$

In 1975 Taylor and David Goodbourn, a fellow tutor at Northern, had attended an international conference on the future of theological education at Windsor which discussed these alternative patterns, in contexts where full time residential training would not be possible. They returned enthused to experiment at Northern. ${ }^{64}$ Taylor's deep involvement in the WCC was also a conduit for influence to come from the developing world: the pedagogical challenges of Freire and the critical reflective approach of liberation theology; the refusal and practical inability to privilege both full time residential training for young men and women and full time stipendiary ministry; the desire to develop extension courses where theological education could run parallel with secular employment and engagement for those already of some Christian maturity. ${ }^{65}$ In September 1978 Leslie Newbigin convened a UK consultation on ministerial training and theological education, which resulted in the establishing of a standing committee on theological education within the British Council of Churches which led to the establishment of a British Working Group on Ministerial Formation in preparation for the WCC all European consultation on Theological Education in Hernnhut, Germany in October 1980. This was followed in 1981 by a major conference held by the Standing Committee on Theological Education of the BCC at which one of the key questions discussed was the residential community as the proper context for the theological education of ministers.

In all of this it was Michael Taylor who was the most significant influence on the practice of the Baptist Colleges. Taylor sat on the WCC committee for the Programme on Theological Education and wrote in its journal Ministerial Formation. His own previous study in the States and his connections round the world exposed him to the American developments of field-work and pastoral care and his commitment, even passion, for ecumenical formation made him a keen observer of other developments in the UK. Such influences as these combined to prompt wide-ranging change.

Northern's APT was alternative in a number of ways, such as the intensity of the course and the age and experience of the majority of the students, but the fundamental change it made was on the priority of the placement of each student. Building on the methodology of Pastoral Studies which understood theology to be critical reflection on practice, the placement was no longer the context in which the theology was applied, but at least as important a place for learning and formation as the College context, if not more so. Education, training and formation happened in two centres and on the basis that the APT was contextual training, the primary base or context should be the local congregation with the College as the outside resource. ${ }^{66}$

To draw our analogy a little further, our case study on ministerial formation suggested that the main place or agent of formation is the practice of ministry itself.

\footnotetext{
62 Most significantly in the 1969 report Ministry Tomorrow (London: BUGB, 1969).

63 See the report in Ministerial Formation 13 (January, 1981).

${ }^{64}$ See Shepherd, The Making of a northern Baptist College, p. 239.

${ }^{65}$ See Leslie Newbigin, 'Theological Education in a World Perspective' in Ministerial Formation 4 (Oct, 1978), pp. 3-8.

66 Michael Taylor, 'Ministerial Training at Northern College'.
} 
Men and women become ministers by being ministers in the local congregation right from the beginning of their training. ${ }^{67}$

The congregation-based pattern then draws its pedagogy significantly from the reflection methods of Pastoral Studies and Practical Theology, common through the stress on field work in the USA. Taylor describes the development of congregation-based patterns of training as a means of teaching students to become theologians, and to integrate theology and practice through reflection, rather than teaching students facts of theology. ${ }^{68}$

Regent's Park College began its congregation-based course (Regent's In-Pastorate Training) in the autumn of 1982, deeply influenced by the 'two centre' pattern at Northern, with five students accepted to study in this way. Spurgeon's, although initially quite critical, considering it had dumbed down serious scholarship and undoubtedly still wary of the associations with Taylor ${ }^{69}$, began to adopt the pattern in 1985 and now the vast majority of ministerial students are on some kind of Congregation-based model, with the experience offered to College-based students also shaped by these pedagogical assumptions. Long essays and field work reports, and later portfolios, came to replace some or all of the traditional seated exams. The teaching of the more academic staff, versed in the more traditional sub-disciplines, was extended with the use of part time or occasional tutors, specialists in a range of subjects that integrated theory and practice together, which led to full time tutors who saw themselves significantly as practical theologians.

The practice has developed from its earliest days. Michael Taylor's original concern for an initial secular placement and so engagement with the world may have dissipated, perhaps along with the early multi-disciplinary efforts of the 1960s, with the experience becoming more self-contained and churchy. Today the stress seems much more on the partnership between church placement and College in the process of formation, rather than the church being the primary centre as Taylor suggested. But experience and methodology had changed for good so that they are now normal and standard across all the Colleges.

\section{The professionalisation of ministry}

One of the more disputed elements in contemporary understandings of ministry concerns the professional identity of the minister, and this in turn has shaped the approaches to ministerial formation. Important discussions among Baptists have taken place in recent decades, but the roots of such professionalisation can be traced much earlier. Farley suggests that following Schleiermacher, and the linking of theology with clergy training, there developed the so-called clerical paradigm, or Wissenschaft approach, which saw theological education as finding its purpose in the training of ministers. ${ }^{70}$ More widely, the founding of University College London in 1828 which took a more utilitarian based approach to education, led the way to the forming of polytechnics which later became Universities, and degrees in single, increasingly vocational subjects. The debate from Locke onwards about the teleological end and utility of education has been settled firmly in recent years by connecting education with employment. The increase in vocational education and training particularly in UK in the 1980s, partly in response to unemployment, and the introduction of NVQs in 1986, with their stress on the development of competence and transferable skills, are clear evidence of this.

The second half of the twentieth century saw the growth of the professions generally and the desire for such professionals to be more clearly educated often with University validation, including methodologies of learning based in practice and critical reflection. Ballard highlights the effect that this wider professional development had on the preparation of ministers, including the dialogue

\footnotetext{
67 Michael Taylor, $2^{\text {nd }}$ lecture on 'The Theology of Spiritual Formation'.

68 Taylor, $2^{\text {nd }}$ lecture on 'The Theology of Spiritual Formation', pp. 4-7.

${ }^{69}$ See Shepherd, Making of a northern College, p. 250.

70 Farley, 'The Curricular Pattern and its Rationale' in Ministerial Formation 14 (April, 1981), pp. 8-11.
} 
between theology and other traditions such as sociology and psychology. ${ }^{11}$ This is then exemplified in the Church of England report of $1976^{72}$ and a syllabus for Pastoral Studies developed in 1978. ${ }^{73}$ The frustration expressed increasingly the 1960s and 1970s by ministers leaving College that they had not been prepared for the practicalities of ministry also led to curricula developments, and although the desire of the Colleges may have been for integration and not just the production of technicians, these changes form part of a wider transition to a different approach to ministry and formation. This is the emphasis on training in the skills needed in order to perform the duties of ministry well.

The rise of the professional training in other spheres seems to coincide with a functional approach to ministry and the greater stress on leadership, a category, of course, which automatically offers significant resonance and greater connections with other spheres of work and life than the language of ministry. Leadership and ministry have often been used interchangeably with little thought, it would seem, about any distinction of meaning. ${ }^{74}$ This increase in the professionalization of ministry and in leadership language happens alongside the change in the student body of the Colleges. Moving away from the residential community of almost exclusively young men, Northern's APT programme was specifically designed to make preparing for ministry possible for more mature students, married with families, and this was paralleled in other Colleges as the Congregation-based approach developed. By 1989 the average age of students at Spurgeon's was 32.4. ${ }^{75}$ Increasingly they brought with them other professional training and management together with leadership experience in secular contexts. This was in a context where Paul Beasley-Murray was Principal from 1986-1992, a strong voice for developing a more professional understanding of ministry. ${ }^{76}$

A further important development in this period is the language of competency, key to the development of secular vocational training. In the early 1980s, at the time when other key changes were being made more widely among the Baptist Colleges, the language of competence is used, though sparingly. The Aims and Objectives of Ministerial Training at Northern Baptist College, from around 1982, does refer in the introduction to the minimum level of competence, but this language does not continue. Michael Taylor brings competence and professionalism together in an address to Baptist ministers when he says that 'this ministry is a profession in that like other professions it can quite properly be expected to be competent - it is qualified, with the knowledge and skills required for the job'. ${ }^{77}$ The more dominant language would seem to be personal qualities rather than competencies. ${ }^{78}$ The 1998 report 'Towards a New List' talks of the three necessary elements necessary for accrediting ministry as call, competence and character.

This is taken further in the work of Bill Allen, then Tutor in Pastoral Studies at Spurgeon's College, developed as part of his doctoral research, which offers a list of seven key competencies for ministry, which would then shape ministerial training. ${ }^{79} \mathrm{~A}$ few years later, partly prompted by the

\footnotetext{
71 Ballard, Foundations of Pastoral Studies, p. 12.

72 Education for Pastoral Ministry, 1976.

73 Ballard, Foundations of Pastoral Studies, p. 16.

${ }^{74}$ So the 'Partners Together' report suddenly slips into using leadership language on page 13 instead of ministry, reporting the belief that churches need additional professional leadership when they reach a certain size (p. 15) with no comment on the use of professional or leadership.

75 Randall, English Baptists of Twentieth Century, p. 451.

${ }^{76}$ See Beasley-Murray's writings, such as Dynamic Leadership: Making it work for you and your Church (Eastbourne: MARC, 1990), Anyone for Ordination (Tunbridge Wells: MARC, 1993) and A Call to Excellence: an Essential Guide to Practical Leadership (London: Hodder and Stoughton, 1995)

77 Michael Taylor, West Midlands Area Ministers Conference, Essays in Ministry 1, 1985 (in private papers in Angus Library).

78 Taylor offers 25 personal qualities in his $14^{\text {th }}$ Atlantic seminar presentation, 1982.

79 Bill Allen, 'Pathways to leadership: The provision of education for training for leadership in the ordained ministry', (University of Wales PhD, 1999); see also, 'Pathways to Leadership' in John Adair and John Nelson, eds., Creative Church Leadership (Norwich: Canterbury Press, 2004). Allen's seven competencies are the ability to: engage in theological reflection and application; construct a foundation of spirituality to undergird ministry; carry out mission and ministry with integrity; communicate in public and private settings; lead others; engage in effective pastoral care and support; manage self and workload in a competent way.
} 
stimulus of the Hind Report and partly from the concerns of a new Head of Ministry a paper went to the Baptist Union Council in August 2005 proposing a number of core competencies, which, although these have been modified in different ways since then, have become increasingly important.

Whereas some warmed to the securing of ministerial status in the professional realm, others reacted against the perceived professionalization of ministry in the 1980s. John Vincent, for example, reflecting on the then current patterns suggests they 'will still produce academic, denominational, professional, hierarchical, status influenced, priestly and rational clergy such as the church denominations decided they needed 100 years ago. ${ }^{80}$

One of the concerns expressed about the clergy paradigm was that it took theology away from the whole church. So alongside the positive influence of professional education, these decades also saw the recovery of the whole church as the pilgrim people of God engaged in ministry and mission, and the need for theological education to include the whole of the Church. This is part of the influence of Vatican II in the Catholic Church and beyond, and at the heart of the WCC's development of its Partnership for Theological Education, working with and building on this ecclesiological renewal and questioning some of the elitist and professional tendencies in ordained ministry ${ }^{81}$.

Among Baptists the commitment of theological education for the whole church was one of Michael Taylor's key early convictions and also one of the conclusions of the report Ministry Tomorrow in 1969. David Russell notes the already developed and attractive programme for training lay people at Bristol in 1971. ${ }^{82}$ The 1998 Report on the partnership between the Union and Colleges stresses the way that theological education for the whole church is the clear commitment of all the Colleges. ${ }^{83}$

Yet within this commitment to wider theological education, the core competencies now feature significantly in all the Baptist Colleges and have shaped the way that curricula have developed and assessment takes place. But there would seem to remain some uncertainty and hesitation about the competencies, both in terms of language and in terms of some of the more functional stress they bring, and there is an on-going search for other language. Jim Gordon, Principal of the Scottish Baptist College, offered a paper at the 2012 Baptist Colleges Staffs' Conference on 'Ministerial Attributes $^{\prime 84}$ as an alternative, more person-centred approach to expressing something of the hoped for pastoral imagination and character of those leaving College.

\section{The importance of ecumenical relationships}

When Michael Taylor was appointed Principal at Northern in 1969 one further key conviction that he expressed was an insistence that ministerial formation needed to be thoroughly ecumenical in its nature. ${ }^{85}$ Acting on this conviction Taylor proceeded to begin discussions with the Congregational College, the Methodists, who moved into Brighton Grove in 1973 when Hartley Victoria College was going to be closed, and the Anglican North Western Ordination Course, resulting in, amongst other things, the Northern Federation for Training in Ministry launched in $1984 .{ }^{86}$

80 John Vincent, 'Theological Education in the 1980s in Britain: Adaptation or Alternatives', Ministerial Formation 10 (April, 1980), p. 9.

${ }^{81}$ Ross Kinsler, 'Ministry by the People' Ministerial Formation 5 (January, 1979), pp. 3-11 compares the need for the ministry of the whole church with the need for primary health care delivered by the community rather than by a few highly trained specialists.

82 Russell, 'The College and its Future', p. 5.

83 'Partners Together', pp. 7-8.

${ }^{84}$ In wider discussion, Michael Fuller and Kenneth Fleming 'Bridging the Gap: A Curriculum Uniting Competencies and Theological Disciplines' JATE 2.2 (2005) pp. 163-178, discuss whether competence is the right language and decide that it can be used in a holistic and 'soft' way to refer to characteristics and attributes rather than a 'hard' way about skills and knowledge. Their eight competencies others might see as attributes.

${ }^{85}$ Shepherd, The Making of a northern College, p. 229.

${ }^{86}$ See Shepherd, pp.244-7 and 253-4. 
Yet Taylor's own determination is in the context of mixed views on the nature of ecumenical training. The establishment of a new and innovative ecumenical College in Birmingham in 1970, The Queens Foundation, made some Baptists at least wonder if they should be part of this process. ${ }^{87}$ On the other hand, the BUGB report on Colleges in 1974, The Report of An Advisory Group and Other Related Documents made available by the Baptist Theological Colleges in England and Wales, seems to have stressed residential training, concentrated on ministerial education and been distinctly cool on ecumenical commitment.

The next two decades saw considerable development in the attitude of the denomination in this respect, represented most significantly by the rise of the Inter Church Process and the Not Strangers but Pilgrims report of 1987. The Union voted to join the new ecumenical process at the Assembly in 1989 (although a quarter of delegates were not in favour) and, although the following few years contained much debate about this decision and the way forward, decisions to formally join CTE and CTBI in 1995 received larger majorities. ${ }^{88}$

In 1986 the Churches Together in England Document Called to be One, looked for opportunities for ministerial students to live alongside each other and explore other traditions. The response of the Union Council the following year stressed the need not just for ministerial students to know something about other traditions, but to immerse themselves in the realities of other traditions. ${ }^{89}$ The Union as a whole, through the Ministry Department, joined the ecumenical inspection process in 2003 organised and administered from Westminster by the Church of England. Again, Taylor's early convictions in time became the mainstream approach.

Currently the five Colleges in membership with BUGB have significant though different ecumenical connections. Northern Baptist Learning Community remains the most ecumenically structured, with its explicit commitment to the Lund Principle and its partnership in the Luther King House federation, with the Methodists, URC, and Unitarians. ${ }^{90}$ Bristol and South Wales have strong bi-party links with their neighbouring Anglican Colleges, Trinity and St Michael's respectively. Regent's is part of the Oxford Partnership for Theological Education and Training with the three Anglican Colleges based in and around Oxford, together with the Catholic Halls. The ecumenical links of Spurgeon's have developed in the areas of the Black and Majority ethnic churches which have often come from an independent Pentecostal heritage. Over half their ministerial students are now from churches other than the Baptist tradition.

\section{The centrality of the mission context}

Baptist understandings of ministry have never been separated from the fundamental mission of the church. Older services of ordination, for example, have included the question to the minister whether she or he will 'do the work of an evangelist' ${ }^{91}$, while more recent publications have structured the charge to the ordinand so that the second question, after one on belief in God as Trinity, seeks a commitment to 'proclaim the good news of Jesus Christ' ${ }^{\prime 2}$. While not, of course, uniquely Baptist it has often been recognised that the 'missionary impulse' is both a Baptist distinctive and a key part of Baptist history and identity. ${ }^{93}$

Yet it is also clear that the changing developments within contemporary culture over recent decades have demanded that clearer and more focussed attention be paid both to the church's

\footnotetext{
${ }^{87}$ Russell, 'Theological Education in the Free Church Tradition'.

88 Randall, English Baptists of Twentieth Century, p. 495.

${ }^{89}$ See 'Partners Together', p. 9.

${ }^{90}$ The Methodist Church centrally is rationalising its ministerial formation and will therefore be pulling out of the Manchester partnership.

${ }^{91}$ Ernest Payne and Stephen Winward, Orders and Prayers for Church Worship (London: Baptist Union of Great Britain and Ireland, $4^{\text {th }}$ edition, 1967), p. 219.

92 See Patterns and Prayers for Christian Worship (Oxford: OUP, 1991), p. 179 and Christopher Ellis and Myra Blyth, eds, Gathering for Worship: Patterns and Prayers for the Community of Disciples (Norwich: Canterbury Press, 2005), p. 124.

93 See Stephen R. Holmes, Baptist Theology (London: T\&T Clark, 2012), pp. 141-3.
} 
missional call and the context in which it was working, so that new and explicit missional thinking became a priority and the church was able to reshape its life so as to engage with changing culture more creatively.

Spurgeon's College responded to this with the development, in 1990, of a specific church planting and evangelism course alongside that for wider or 'pastoral' ministry, initiated by Stuart Christine and developed by Stuart Murray on his appointment in 1992. During this time around half the modules taught were in conjunction with the pastoral ministry track with the other half unique to the Church Planting and Evangelism course. This particular approach lasted until the early 2000s when Spurgeon's sought to respond to the proposal to add the categories of ordained and accredited youth specialists and more particularly ordained and accredited evangelists alongside that of the ordained Pastor, a decision agreed at the Baptist Union Council in March 2001. This seemed no desire to downplay the missional work in which all pastoral ministers would engage - to do the work of an evangelist - but to offer recognition of a specific calling in the light of the need for a more explicit missional refocusing of the church.

The reality and impact may have been slightly different. Turning again to the most recent collection of patterns for ordination services, and the only one produced since the ordination of evangelists, after initial questions on belief in God, making disciples and being a disciple, the pattern then suggests different questions for pastors, youth specialists and evangelists. While the question for youth specialists refers to 'those young people entrusted in your care', evangelists are asked, 'Will you witness to the gospel of Jesus Christ in a needy world and amongst those who do not know his name? Will you seek to be a minster of peace, a sharer of love and a sign of hope?'94

Although undoubtedly an appropriate question in its own right, theologically Baptists have wanted to assert that this is the calling of all disciples and central to the work of all ministers. Although recognising the specific callings and giftings of those who have prepared and are preparing for ministry, the danger and difficulty, as expressed in the forming of words for an ordination service, is that pastoral ministry and evangelism become too sharply differentiated.

The Colleges, perhaps alert to this danger, have placed greater stress on integrating the pastoral ministry and the evangelism track together, as different emphases within one course, which as a whole has developed a more explicit and culturally relevant missional feel. Again, in recent years there has been some resistance from Colleges to the idea of a quite separate church planting or pioneer course, seeking a greater integration of pioneering mission across all ministerial formation, alongside opportunities for some to focus more on pioneering ministry.$^{95}$ Regent's for example, in 2010, began a partnership with Pioneer Leadership Programme which is part of CMS, both to provide input into the wider ministerial course and to offer extra opportunities as a track for those seeking to be pioneer evangelists. Bristol, also since 2010, has offered the most distinct pathway through ministerial formation in urban mission and church planting as part of the re:source initiative in Bristol and in partnership with Urban Expression, in which part of the overall course is shared with all ministerial students and part is distinct and unique.

One further aspect of the changing missional context is the partnership which all the Colleges have had in recent years with BMS World Mission. In March / April 2008 Bristol took the first student teams abroad to India and Brazil with BMS World Mission, with the other four Colleges following soon after. This seems to reflect a more significant place for what the global church could contribute to the formation of ministers in the UK and the significant learning and experience of BMS.

Culturally relevant, globally sensitive and alert to the need for a greater emphasis on pioneering ministry: this would seem to reflect the Colleges' desire for contemporary ministerial formation for all ministers, in which there would also be space for a variety of particular specialisms to grow.

\section{The emergence of the formation paradigm}

\footnotetext{
${ }^{94}$ Ellis and Blyth, Gathering for Worship, p. 125.

95 Based on discussions at the 2010 annual Baptist Staffs Conference.
} 
The Baptist Union document with which we began suggested that while formation has become the key descriptor for preparation for ministry, this has not always been the case. In fact formation as the dominant paradigm is a recent development. The language seems to originate and develop in the Roman Catholic Church, although there is the intriguing reference to the work of Hugh Evans, Principal at Bristol in the later part of the eighteenth century as 'forming them able, evangelical, lively, zealous ministers of the Gospel. ${ }^{\prime 96}$ John Henry, Cardinal, Newman in the middle of the nineteenth century, in his lectures in support of a new exclusively Catholic University in Dublin, brings together the intellectual and spiritual in a University setting in a way which has significant modern resonances. He speaks of the way 'a habit of mind is formed which lasts a life time' ${ }^{\prime 97}$ and that a University education quite explicitly concerns the formation of character. Mike Higton summarises Newman's understanding of university education, based on his experience at Oxford and hopes for Dublin, as 'a school of intellectual virtue, forming its students as human beings, citizens and professionals' ${ }^{\prime 98}$ and as 'formation in counter-cultural intellectual virtue: in patient questioning and the pursuit of coherence or integrity. ${ }^{\prime 9}$

Andrew Mayes traces other early Catholic usage from the mid eighteenth century, where formation is occasionally applied specifically to the development of ordinands in spirituality and holiness, developing in the twentieth century to a wider meaning, in some places, virtually equivalent to education. ${ }^{100}$ This development is boosted in and after Vatican II, with some of the texts referring more explicitly to different aspects of formation, but generally referring to the development of spirituality as distinct from academic study. ${ }^{101} \mathrm{~A}$ major change came in 1977 when the World Council of Churches re-thought and re-structured their existing explorations into theological education, and replaced the Theological Education Fund with the new Partnership for Theological Education (PTE), and with it came a new Journal, or newsletter as the early editions appeared to be, simply entitled Ministerial Formation. ${ }^{102}$ It attempts no definitive definition, yet an early edition suggested this was a holistic process involving: intellectual resourcefulness, awareness of God and sensitivity to real human problems, the assimilation of appropriate skills, enrichment in exemplary spirituality and a commitment to congregations and people. ${ }^{103}$ Ministerial Formation was now at the centre of ecumenical discussions.

Baptists appear, to some degree, to be early adopters of this language, although Baptist ecclesiology means it is harder to follow the development through official central documents as in other denominations. ${ }^{104}$ As a member of the Initial PTE Commission and regular contributor to Ministerial Formation Michael Taylor was involved in these developments from the beginning and was a conduit to the wider Baptist denomination. He writes in 1979 that one of the perplexities that remained was 'how to form persons and not just train minds or develop skills' ${ }^{105}$. In 1982, in a series of lectures, Taylor explores the different uses of the word and the scope of its meaning, asserting his preference for the term personal formation (spiritual formation seeming to separate out the spiritual from the rest of life), by which he means the entirety of the process of preparing for ministry as an aspect of the on-going formation of the people of God. Yet he concedes that 'we do, in my world, pay lip-service to formation in the more all-embracing sense to which I have

\footnotetext{
${ }^{96}$ Quoted in Chris Ellis, 'Being a Minister: Spirituality and the Pastor' in Pieter Lalleman, ed., Challenging to Change: dialogues with a radical Baptist theologian (London: Spurgeon's College, 2009), p. 57.

97 J. H .Newman, Discourse 5 'Knowledge its Own End' in The Idea of a University (New York: Image Books, 1959), p. 129.

98 Mike Higton, A Theology of Higher Education (Oxford: OUP, 2012), p. 80.

99 Higton, Higher Education, p. 90.

100 Mayes, Spirituality in Ministerial Formation, (Cardiff: University of Wales, 2009) pp. 35-8.

101 Mayes, Spirituality in Ministerial Formation, p. 42.

102 The first edition appeared in January 1978 and it continues to be published by the WCC in Geneva.

${ }^{103}$ Aharon Sapsezian, 'Exploring the Nature of Ministerial Formation: An Invitation to Dialogue' in Ministerial Formation 5 (1979), pp. 20-21.

${ }^{104}$ It is perhaps for this reason that Andrew Mayes' quite extensive review of formation language touches on the various other historic denominations but with no mention at all of Baptists!

105 Michael Taylor, 'The Free Churches Selection and Training' in Christian World (Jan 1979).
} 
referred.' ${ }^{106}$ In 1983 Taylor gave a paper to the Baptist Colleges Staffs Conference on 'Ministerial Formation', out of which plans were made that the following year's conference would be around the theme of 'Formation of Persons for Ministry' and 'Education as the Formation of Persons'. ${ }^{107}$

In 1987, the Church of England produced a significant report on the future of Ministry, Education for the Church's Ministry, often known as ACCM 22, ${ }^{108}$ which begins their tentative use of formation language. This is further consolidated in subsequent years by further reports, Theology in Practice and Integration and Assessment. ${ }^{109}$ At the same time in 1992 the Papal Encyclical Pastores Dabo Vobis from John Paul II, uses formation language as the dominant paradigm and refers to human, spiritual, intellectual and pastoral formation. Later in that decade the Methodists discuss the preparation for ordained ministry in some depth through their report, The Making of Ministry which leads to formation language being the dominant paradigm adopted at the Methodist Conference in 1999. A major further step forward in the wider development of the whole formation paradigm was the process which produced Formation for Ministry within a Learning Church in the Church of England, known more commonly as The Hind Report, after its Chairman, which sees formation as the central model not just one aspect of the whole - and it was very much a process, as the second and final report uses formation language to a much greater degree than the first published drafts. ${ }^{110}$

Although the last twenty five years have seen a move into the formation paradigm the use of such language has been neither consistent nor universally accepted. Three different aspects stand out.

First, the word 'formation' itself is used in different ways, with two main possibilities. It is sometimes used to refer to one aspect of the process of preparation for ordination, which particularly centres around issues of spirituality and character. In this sense it is in addition to other aspects, often described as education and training, and maybe referred to, for example, as spiritual formation. But it is also used, as in the Baptist Union document quoted at the very beginning, to refer to the whole process of preparation of which education and training and the development of character are a part. So the recent paper 'Ministry and Mission: Direction of Travel' as part of the Common Awards process uses formation as distinct to cognitive and skills based learning as part of a holistic process, as well as the overarching term. ${ }^{111}$

It is true, of course, the words education and training have also been used to describe the whole process as well as individual parts of it. We have seen how in the nineteenth century Newman saw education in deeply formative and spiritual ways. One of the struggles has been the difficulty of finding a different single word which might stand for that part of the whole which is more focussed on the development of character and spirituality, thus formation slips into both meanings.

Secondly, there often is little clarity between the words education, training and formation. The questionnaire documentation sent by the Quality in Formation Panel to Colleges and Courses to be inspected is typical of the confusion. ${ }^{112}$ The language of education, training and formation are at times used interchangeably, although it is the language of training which is still most dominant. Invariably Colleges and Courses are referred to as training institutions, and, in an echo of our previous point the documentation can refer to 'ministerial, personal and spiritual formation' ${ }^{113}$ with no discussion of any differences in these terms, or simply to 'ministerial formation'. The over-riding

106 Taylor, 1st lecture, $14^{\text {th }}$ Atlantic Seminar in Theological Education, p. 6. A letter from Brian (presumably Haymes, a tutor at Northern) to Taylor as Principal in 1982 reveals the debate among staff there about the language, with the language of training still dominating but with a clear growing belief in the language and idea of formation (in Michael Taylor's personal papers in Angus library).

107 Minutes of The Baptist Colleges Staffs Conference (in the Angus library).

${ }^{108}$ Education for the Church's Ministry (London: Church House Publishing, 1987).

109 Theology in Practice (London: Church House Publishing, 1998) and Integration and Assessment (London: Church House Publishing, 1992).

110 For a fuller account of these developments see Mayes, Spirituality in Ministerial Formation, Chs 3 and 4.

${ }^{111}$ Church of England, 'Ministry and Mission: Direction of Travel' (July, 2012), pp. 3-4.

112 'Quality Assurance and Enhancement in Ministerial Education: Inspection, Curriculum Approval, Moderation' 2010.

113 (Quality Assurance and Enhancement', p. 26. This is the title for Section F. 
impression is that there is no clear understanding of formation in this handbook and no clear distinction between formation, education and training.

A document on restructuring the Union's Accredited list in 1998 can refer simply to ministerial formation without any further explanation ${ }^{114}$, assuming that such language would be understood. Yet other Union documents and articles by College staff from the same period will refer simply to ministerial training, ${ }^{115}$ and the report on the Colleges and the Union, also in 1998, can use education, training and formation, seemingly interchangeably, and although it explicitly proposes a holistic sense of formation, training language still significantly dominates. ${ }^{116}$ Although Baptists may speak of this overall process of 'ministerial formation', those preparing for ministry, especially those Congregation-based are known as 'Ministers-in-Training'. Having been given access for a research project to the documentation of the five Colleges in membership of BUGB it is possible to trace the way that language has developed in all of the Colleges, for example with earlier versions of Handbooks predominantly using training language, which has been gradually changed to place more emphasis on formation. ${ }^{117}$ In a survey of the websites of the British Baptist Colleges in the summer of 2012, there was very little mention of ministerial formation and the majority of Colleges simply referred here to ministerial training, despite other significant internal documents stressing formation. It may be that there is some implicit sense that 'training' may communicate more easily with those outside of the Colleges, or simply that websites tend to lag behind and need updating. Clearly even in the last few years the use of language has been very flexible and fluid.

Thirdly there has been some resistance to the language of formation in a number of places. The URC nationally has been much more cautious of formation language, considering it to suggest an elitist and ontological understanding of ministry. ${ }^{118}$ This alerts us to the theological presuppositions about the nature of ministry behind developments in formation. Certainly the language of formation with its person centred and holistic stress fits easily with an understanding of ministry as 'being' rather than simply 'doing'. For some, the fact that the language has emerged from the Catholic tradition has not been helpful. Others may use the language but are concerned that formation may too easily be seen as 'conformation' to a predetermined pattern, suggesting too great a centralisation by ecclesiastical authorities. ${ }^{119}$ This is, in fact, a very nuanced discussion. It has been recognised that all education implies some kind of formation, where this formation is to a particular understanding or belief or tradition. The nuance of the discussion centres on the balance between the formative and critical elements in an educational process. ${ }^{120}$ Baptist ministerial formation happens as part of the overall Christian formation into the image of Christ and can only do so within the particular Baptist tradition of understanding Scripture and Church and Ministry. We must therefore expect some element of being shaped by and into the particular tradition alongside the freedom to critique it.

In spite of these ambiguities and concerns there has been a clear development, what we have referred to as the formation paradigm, such that the language of ministerial formation is now commonly, if not entirely used, and used to refer to the whole of the process, encapsulating and integrating all its different aspects. The recent Baptist Union document 'Patterns of Ministry Among

\footnotetext{
114 'Towards a New List'.

115 See, for example, Nigel Wright, 'Ministry: Towards a Consensus' for the Doctrine and Worship Committee, 2000; John Weaver, 'The Future of Ministerial Training', The Baptist Ministers Journal 250 (Jan, 1995).

116 'Partners Together'.

117 Mayes concludes from his empirical research in Anglican Colleges that there has been the same gradual change in language.

118 Mayes, Spirituality in Ministerial Formation, p. 64.

${ }^{119}$ For example as expressed in an interview with Richard Kidd, Principal of Northern Baptist Learning Community until 2012.

120 For a fuller discussion see Jeff Astley, See also Bryan Pettifer, 'Education and the Knowledge of God: Toward a model of Theology as a Practical Discipline' Field' in Ballard, ed., Foundations of Pastoral Studies, p. 66: Education is 'not a passing on of information but part of the process of initiation both into particular knowledge and into the wider society that values that knowledge or sanctions those beliefs.'
} 
Baptists' follows this clear understanding and trend echoing very strongly, and unsurprisingly, the position of the Hind Report in this regard. ${ }^{121}$

Among the Baptist Colleges this has often been represented by the language of 'head, heart and hands' and 'knowing, being, doing' or the image of three interlocking circles, drawn from the work of Bill Allen when he was tutor for at Spurgeon's College. ${ }^{122}$

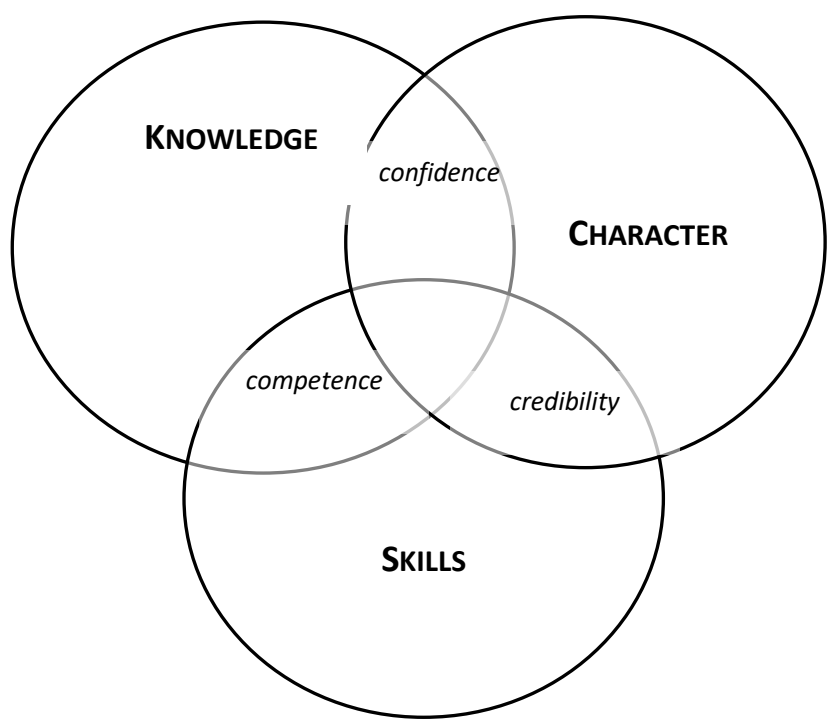

Not only does Mayes chart some of the linguistic changes he also concludes that 'this is not just a change in semantics, but represents the embracing of a new dynamic model of learning that resonates with ancient concepts and yet challenges some inherited patterns of training. ${ }^{123}$ This, however, needs to be stated carefully. Before the rise of Pastoral Studies and Congregation-based patterns when predominantly young men studied for University Degrees in residential communities, there would have been the same underlying fundamental concern for Christian maturity and deep spirituality, and some expectation that both academic study and living in a semi-monastic community of a seminary centred upon corporate worship and shared life would naturally shape the students. ${ }^{124}$ The experience of students may well have been that there was little if any explicit mention of character or spirituality, but David Russell, in 1971, speaks of 'the need to wrestle with truth and be prepared to pay the price of distress and doubt in order to possess $i^{125}$, ideas which would be considered deeply formational in contemporary language. Norman Moon reflects on the purpose of the College at Bristol, and expresses what would have been the common view. 'The primary task of a theological College is not merely to teach, certainly not to indoctrinate, nor merely

${ }^{121}$ Formation for Ministry within a Learning Church (London: Church House Publishing, 2003), p. 29: 'It is also important not to understand formation as being concerned solely with the question of spirituality and discipleship which is then added as a third element alongside 'education' (= academic study) and 'training' (= learning skills for ministry). Rather formation should be seen as the overarching concept that integrates the person, understanding and competence.'

122 The origins of this model are in Bill Allen's PhD, 'Pathways to leadership'.

123 Mayes, Spirituality for Ministerial Formation, p. 72.

124 Taylor, 1st lecture, 14 ${ }^{\text {th }}$ Atlantic Seminar in Theological Education, p. 7: 'having acknowledged this, in my tradition at least, we tend to leave it to look after itself. Great faith is often put in the college community... being forced to live with other students in training, having to maintain good relations with them, 'knocking spots' off each other, smoothing rough corners, sharing the times of doubt and faith, giving and receiving in fellowship with a common aim, these are the dynamic realities which can be trusted to mould raw material into suitable characters for ordination.'

125 Russell, 'The College and its Future', p. 4. 
to train in techniques, but to help students grow as persons, Christian men and women. For such a purpose the residential community is most valuable in itself. ${ }^{\prime 26}$

What the emergence of the formation paradigm has done is to bring together these tangled roots in a much clearer way. This understanding takes some of the historical aspects of College life and makes them both explicit, where they may have been assumed, integrated, where they would have been separate, and applicable to those not part of the residential community. These seem to be the particular advantages of this development. Formation can also understand the process of preparation for ministry as deeply connected to the whole of Christian discipleship, being formed into the image of Christ, an experience, as expressed by one current Principal, which is intensive and intentional ${ }^{127}$, and alongside the explicit and integrative approaches methodologies and pedagogies have developed and changed as well to reflect this approach.

\section{Conclusion}

We have identified eight particular aspects which have developed often interchangeably and with significant inter-dependence, and which have formed the contemporary practice of ministerial formation. Who we are today as Colleges and what we do has been shaped by this history. We might summarise the influence of these tangled roots in a number of contemporary commitments:

- to open, critical and rigorous study in partnership with the wider secular academy, symbolised by University validation;

- to the integration of theology and practice and the importance of placement experience

- to the methodology of practical theology;

- to an understanding of theology itself as an integrated whole which is focussed on the knowledge of God;

- to the formation of ministers around an agreed set of core competencies;

- to the formation of Baptist ministers in the wider context of the Universal Church and so the intentional sharing of the journey in a variety of ecumenical contexts;

- to the formation of ministers alert to and engaging in the contemporary mission context aware of the insights of the global church;

- to the formation of the whole person, integrating knowledge, skills and character as an aspect of the formation of the whole people of God.

This is not to suggest that there are no differences between the Colleges or that these current emphases will not be refined, challenged or changed, but this, with significant agreement and mutual respect and partnership, is where the British Colleges stand today.

Anthony Clarke is Fellow and Tutor in Pastoral Studies and Community Learning at Regent's Park College, Oxford, and a member of the Faculty of Theology and Religion in the University of Oxford.

Correspondence to anthony.clarke@regents.ox.ac.uk

${ }^{126}$ Moon, Education for Ministry, p. 98.

127 Steve Finamore, Principal of Bristol Baptist College, in an interview. 


\section{Bibliography}

\section{Baptist Documents}

- Ministry Tomorrow in Roger Hayden (ed.) Baptist Union Documents 1948-77 (London: Baptist Historical Society, 1980)

- The Report of An Advisory Group and Other Related Documents made available by the Baptist Theological Colleges in England and Wales (1974)

- Patterns and Prayers for Christian Worship (Oxford: OUP, 1991)

- Nigel Wright, 'New Thoughts on Old Ministries' (January, 1993)

- Chris Ellis and Malcolm Goodspeed, 'Towards a New List: Proposals for the Restructuring of the List of Accredited Ministers of the Baptist Union of Great Britain (Draft 5), Doctrine and Worship Committee(July, 1998)

- 'Partners Together - The Colleges and the rest of the Baptist Union of Great Britain' - The Report of the Union / Colleges Partnership Task Group (August, 1998)

- Nigel Wright, 'Ministry: Towards a Consensus' for the Doctrine and Worship Committee, (2000)

- Patterns of Ministry among Baptists: A Review of The Register of Covenanted Persons Accredited for Ministry A Report of the 'Review of the Register Working Group', presented to BUGB Council (November, 2011)

\section{Church of England Documents}

- Education for Pastoral Ministry (London: Church House Publishing, 1976)

- Theology in Practice (London: Church House Publishing, 1998) and Integration and Assessment (London: Church House Publishing, 1992)

- Formation for Ministry within a Learning Church (London: Church House Publishing, 2003)

- 'Quality Assurance and Enhancement in Ministerial Education: Inspection, Curriculum Approval, Moderation' (2010)

- Church of England, 'Ministry and Mission: Direction of Travel' (July, 2012) pp. 3-4.

\section{Papers from the Angus library}

Michael Taylor

- Paper for Ecumenical Consultation on the role of Theological Colleges (1975)

- $1^{\text {st }}$ and $2^{\text {nd }}$ lectures on 'The Theology of Spiritual Formation' at $14^{\text {th }}$ Atlantic Seminar in Theological Education (1982)

- West Midlands Area Ministers Conference, Essays in Ministry 1 and 2 (1985)

- Various correspondence

David Russell

- 'Practical Training for the Ministry in Britain' (1964)

- 'Theological Education in the Free Church Tradition: The British Situation'

- 'The College and its Future', an address given on the retirement of L G Champion and the inauguration of WMS West as President of Bristol Baptist College (1971)

Regent's Park College Council and Executive Minutes

\section{Books and Articles:}


Bill Allen, 'Pathways to leadership: The provision of education for training for leadership in the ordained ministry', (University of Wales PhD, 1999)

Bill Allen, 'Pathways to Leadership' in John Adair and John Nelson (eds.), Creative Church Leadership (Norwich: Canterbury Press, 2004)

Paul Ballard, 'The Emergence of Pastoral Studies' in Ballard (ed.), Foundations of Pastoral Studies and Practical Theology

Paul Ballard (ed.), Foundations of Pastoral Studies and Practical Theology (Cardiff: University College, 1986)

R E Cooper, From Stepney to St Giles': The Story of Regent's Park College 1810-1960 (London: Carey Kingsgate, 1960)

Christopher Ellis and Myra Blyth (eds), Gathering for Worship: Patterns and Prayers for the Community of Disciples (Norwich: Canterbury Press, 2005)

Edward Farley 'The Curricular Pattern and its Rationale as an Issue in the Reform of North American Theological Education' in Ministerial Formation (Geneva: WCC, vol 14, April 1981) pp. 8-11

Michael Fuller and Kenneth Fleming 'Bridging the Gap: A Curriculum Uniting Competencies and Theological Disciplines' JATE 2.2 (2005) pp. 163-178

John Hadsell, 'Faith's Understanding' in Ministerial Formation vol 26 (May, 1984)

Mike Higton, A Theology of Higher Education (Oxford: OUP, 2012)

Stephen R Holmes, Baptist Theology (London: T\&T Clark, 2012)

David Kelsey, Between Athens and Berlin: The Theological Education Debate (Grand Rapids, MI:

Eerdmans, 1993)

Ross Kinsler, 'Ministry by the People' in Ministerial Formation vol 5 (January 1979) pp. 3-11

D Hugh Matthews, From Abergavenny to Cardiff: History of South Wales Baptist College (1806-2006) (Abertawe: Gwasg Ilston, 2007)

Andrew Mayes, Spirituality in Ministerial Formation, (Cardiff: University of Wales, 2009)

Norman Moon, Education for Ministry (Bristol: Bristol Baptist College)

J H Newman, Discourse 5 'Knowledge its Own End' in The Idea of a University (New York: Image, 1959)

Mike Nicholls, Lights to the World: A History of Spurgeon's College 1856-1992 (Harpenden: Nuprint, 1994)

See Leslie Newbigin, 'Theological Education in a World Perspective' in Ministerial Formation vol 4, (Oct, 1978) pp. 3-8

John Nicholson 'Changing Attitudes' in The Fraternal vol 269 (Jan, 2000)

Stephen Pattison, 'Research, Resources and Threats' in Ballard (ed.), Foundations of Pastoral Studies

Ernest Payne and Stephen Winward, Orders and Prayers for Church Worship (London: Baptist Union of Great Britain and Ireland, $4^{\text {th }}$ edition, 1967)

Bryan Pettifer, 'Education and the Knowledge of God: Towards a model of Theology as a Practical Discipline in Ballard (ed.), Foundations of Pastoral Studies

Ian Randall, The English Baptists of the Twentieth Century (Didcot: Baptist Historical Society, 2005)

Peter Shepherd, The Making of a northern Baptist College (Manchester: Northern Baptist College, 2004)

Douglas Sparkes, An Accredited Ministry (Didcot: Baptist Historical Society, 1996)

Aharon Sapsezian, 'Exploring the Nature of Ministerial Formation: An Invitation to Dialogue' in Ministerial Formation vol 5 (1979) 
Michael Taylor, 'The Free Churches Selection and Training' in Christian World (Jan, 1979)

Michael Taylor, 'Ministerial Training at Northern College' in The Fraternal vol 196, (July, 1981) pp. 412

Stephen Toulmin 'Theology in the Context of the University' in Jeff Astley (ed.) Theological Perspectives in Christian Formation (Leominster: Gracewing, 1996)

John Vincent, 'Theological Education in the 1980s in Britain: Adaptation or Alternatives, in Ministerial Formation, vol 10 (April, 1980)

John Weaver, 'The Future of Ministerial Training' in the Baptist Ministers Journal vol 250 (Jan, 1995) John Wesson, 'How Cinderella might get to the Ball: Pastoral Studies and its Relation to Theology' in Ballard (ed.), Foundations of Pastoral Studies

Michael Williams, 'The Dichotomy between Faith and Action: Towards a Model for 'Doing Theology" in Ballard (ed.), Foundations of Pastoral Studies 